Nora Bonner

Miami University of Ohio
Elham Shayegh

Miami University of Ohio

\title{
Adam Bede Revisited: Social Stigma and the Formation of Deviant Identity
}

\begin{abstract}
In Adam Bede, George Eliot explores the way a society divides its members into categories and how these categories contribute to the formation of an individual's identity. In the mid-nineteenth century authors in the naturalist tradition often discussed this dialogical relationship between individual and society, the specific roles for social gaze, the labeling and degrading. Eliot shows an acute of these labels that no one shapes identity without their influence. According to Nancy Anne Marck, Adam Bede introduces the theme of "emerging social consciousness" where the characters gain broader awareness of human interdependence through an experience of suffering (447). This is particularly evident when examining Eliot's characters of "lesser fortune." Once we've investigated how Eliot portrays these negative social forces throughout the novel, the labeling and the stigmatization, we will return to how Eliot addresses the larger question permeating her novel of education: how one judges another against the backdrop of community values.
\end{abstract}

Keywords: stigmatization, social identity, gaze, realism/naturalism, ethics in narrative style

Erving Goffman gives insight to social labeling and the stigmatization in his book, Stigma Notes on the Management of Spoiled Identity. He defines stigma as "the phenomenon whereby an individual with an attribute which is deeply discredited by his/her society is rejected as a result of the attribute" (Goffman 36). In other words, stigma occurs when society recognizes an individual as deviant, thus creating the negative stereotypes that engender prejudiced attitudes. The crimes committed in response to this labeling are "deviations." Stigmas therefore justify discriminatory behavior. Goffman names two types of social identity: actual and virtual. The former refers to a person's social existence-his or her condition in "reality," - while virtual identity refers to "what is expected of someone based on who, what, or where s/he is" (36). These definitions give insight into how one might understand Eliot's tragic heroine, Hetty Sorrel.

Throughout the novel, Hayslope community ${ }^{1}$ refuses to allow Hetty a comfortable position in their society. They elevate her as a most desired object until she believes her higher position, and

1 A rural community in Loamshire England, 1799. Loamshire is an imaginary rural county, used as a setting by writers of fiction to avoid identification with actual towns. 
until "her dreams were all of luxuries" (Eliot 102). Their praises push her somewhere between her actual and virtual identities, convincing her that she is qualified for marrying the young squire, captain Arthur Donnithorne: “The baker's daughter [Hetty] goes home and dreams of the handsome young emperor, and perhaps weighs the flour amiss while she is thinking what a heavenly lot it must be to have him for a husband" (105). From this description, it is clear that Hetty's dreams are too lofty to be realistic, mainly because of her ignorance of class difference. Eliot emphasizes this later with Arthur's description of the same encounter: "To flirt with Hetty was a very different affair from flirting with a pretty girl of his own station: that was understood to be an amusement on both sides, or, if it became serious, there was no obstacle to marriage" (144). Hetty never resolves the conflict between her virtual and actual identities because she never finds a way to Arthur's hidden intentions, and finally disappointed by him, she was stigmatized by Hayslope as the undesired other. She is now the deviant, the criminal. The fatal sin of murdering her newborn as the narrative implies is a socially constructed crime but the community does not hold itself responsible for it. According to Courtney Berger in "Liability and Individual Consciousness in Adam Bede":

Eliot's early work is indicative of her desire to portray a social world in which individuals both help to constitute and are answerable to the standards of the group. Particularly in her early fiction, we see Eliot endeavoring to develop a theory of the social individual that withstands her concomitant endorsement of what we might call "pluralist" and "universalist" conception of morality-that is, judging individuals according to the standards of the group versus a single comprehensive standard (308).

Eliot acknowledges the individual's inevitable role in identity formations. She addresses a person's capabilities and limitations in $19^{\text {th }}$-century British society through her other female heroine, Dinah, whose choices defy the imposed stigmas. Dinah's character often directly contrasts Hetty, initially evident in the physical descriptions of the two women. For Dinah, "Her eyes had no peculiar beauty, beyond that of expression; so simple, so candid, so gravely loving, that no accusing scowl, no light sneer could help melting away before their glance" (Eliot 22). Dinah's attractiveness comes from her expressions rather than her features-what she does and does not do with her face. Similar to Dinah, the majority of Hetty's physical description does not focus on specific physical features but on the reactions that those features get from men gazing at her. In Hetty's case, however, these reactions and sensations overwhelm the gazer, cause confusion, and appear out of her control:

It is a beauty like that of kittens, or very small downy ducks making gentle rippling noises with their soft bills, or babies just beginning to toddle and to engage in conscious mischief--a beauty with which you can never be angry, but that you feel ready to crush for inability to comprehend the state of mind into which it throws you (86).

The contrast between Dinah's authority over the way people react to her and Hetty's lack of it reveals the novel's juxtaposing theme of personal choice as a way to defy social stigma. Dinah is 
a devout Methodist, a preacher who persuades the community of her authority and leadership in the way she cares for others. After the town rejects Hetty for her crime of infanticide, it is Dinah who visits her in jail and consoles her. Dinah is determined to never marry, freeing herself from Hayslope's social expectations for women. However, after this set up, and just when the reader might decide that Dinah has defied society's expectations, Dinah changes course and becomes Adam's wife. We could interpret her decision to marry as a failure as she's still unable to survive outside the social norms. Dinah's story reveals that even at our most rebellious state, we submit ourselves to some sort of mold. On the other hand, the marriage might be read as another sort of defiance, a triumph over the constraints she'd imposed on herself.

In the first place, we might read these women's stories together as a juxtaposition-one pitched against the other as a way to verify a lesson for better choices in Dinah's happier ending. "Dinah represents the Second Eve [Mary], Hetty epitomizes the First" (Marr 87). In Hetty, the novel provides a karmic view of life in which she must pay the consequences of her actions: "Our deeds determine us, as much as we determine our deeds" (Eliot 328). On the other hand, we might read the stories to see how they reveal the feminine struggle against Victorian social norms and stigmas. Critics have identified Eliot as a woman writer with awareness of the realities of a male-dominated world (Beer 73). Both Dianah and Hetty, in this sense, fall under the authority of Hayslope patriarchal elements of gender and moral rules.

Hetty represents the working class girl who destroys her life for the love of luxury and comfort. Hetty's dream of luxury is not a simple longing for material possession but a desire for liberation from Hayslope's patriarchal expectations for her. Luxuriousness became that characteristic through which Hetty preserves her individuality. Hetty in her blind passion keeps dreaming about her future wellbeing, the time when Arthur would "marry her and make a lady of her" (157).

Perhaps some day she should be a grand lady, and ride in her coach, and dress for dinner in a brocaded silk, with feathers in her hair, and her dress sweeping the ground... her hair is done in a great many different ways, and some time in a pink dress, and sometimes in a white one-she doesn't know which one she liked best (158).

In this dreamy "world of brilliant costumes" (262), she desires to "cast all her past [life] behind" (160) and elevate her status to that of a reputable lady. She is dissatisfied with her status and wishes to escape from the society that embodies a "sickening sense of monotonous life" (350). In this way, the desire for luxury is a substitute for her suppressed actual identity. She was denied to work as a "lady's maid" because it would be a humiliation to her uncle, a "laborer" who would like to eat on his "own labor" rather than waiting for people's "charity" (353). As a young girl, she was not permitted to walk in the fields "alone" and come home late, or she would be the object of her aunt's reproachful inquiries. Social restraints become most evident when her dedicated lover, Adam Bede, also questions her behavior. Criticizing her for putting a rose in her hairs, he comments that Hetty's way of dressing was not as modest as Dinah's (238). She then reacts to his critique by wearing a "black gown of her aunt's" in the style of Methodists, thus performing a virtuous identity. As 
the novel progress, Hetty's pretense and loss of desired feminine attributes (causing loss of actual identity) become essential for her social survival. According to Marck, throughout the novel,

Hetty's alienation extends from her own body to her family, to the community of Hayslope, to society at large, and even to nature-the charge of infanticide constructs her as a monstrous female, guilty of a crime against the biological, social, and psychological expectations of motherhood (448).

What is obvious in the novel is the oppressive power of society, which gradually silences the voices of the marginalized citizens, namely the working class and women. The similarity between animals and women, which Eliot emphasizes throughout the novel, suggests a feminine voicelessness. Gyp and Vixen the dogs, and Meg the horse are all female, implying that women are preferred to be silent, obedient and dependent. The society desires "to convert Dinah the preacher... into a convenient household slave" (509). Eliot criticizes this feminine silence through her female characters (the talkative Mrs. Poyser and the eloquent Dinah), and their desires (Hetty seeks refuge in dream of luxurious life and Dinah in religion). Both Hetty and Dinah attempt to express their suffocated self through male figures. Hetty and Dinah are the double faces of the same reality when, at the doorway of their "bed chambers," their "pale faces... looking at each other" (467) suddenly "become indistinct" (468). The fusion of their feminine silence under the voice of a female narrator itself concealed under the male name George Eliot, narrates Hetty's story under the title Adam Bede, and presents Victorian marginalized femininity.

The novel's repetitive references to spectacles and eyeglasses intensify the concept of social gaze. The gaze restrains everyone but primarily women, bringing their lives to foreground. Spectating Hetty at the dance party, Lady Irwine declares to her son that as she gets older, her eyes "get better and better for things at the distance" (others) while her near-sightedness worsens (286). Hetty specially becomes aware of social gaze near the murder scene, when "for the first time in her life [she] wished no one would look at her" (391). Her awareness then reaches its climax in the trial scene. We read that the judge is a fellow "with an eye that 'ud pick the needles out of the hay in no time" (447). Gerhard Falk refers to court trials as instances of imposed social stigmatizations:

Conviction in a court of law... the most important part of the stigmatization process are status-reduction emotions such as a "hearing," a "trial," and the establishment of a public record of such a procedure. Sociologists refer to these transactions as "degradation ceremonies." These place the individual affected outside the legitimate order and outside the world of citizens of good standing (Falk 330).

We might read the trial scene as a degradation ceremony where the Hayslope community judges and convicts Hetty as criminal without considering her maternal trauma. Falk also mentions "secondary deviations" (313) as a way to define the consequences of labeling. These deviations occur when an "individual changes his or her behavior and self-definition to internalize society's stigmatization; the person then begins to behave in 'expected deviant' fashion" (Scheyett). In this light, adultery as Hetty's "secondary deviation" is a response to society's stigmatization of her "naughty"-ness, which leads to her third deviation, infanticide. Sociologists call this last stage the 
"dramatization of evil," when the victims start to take on the traits associated with the stigma society imposed on them (Falk 330).

According to Michel Foucault, stigmatization is a "discourse of power" (Foucault). Naming five attributes of stigma in their essay "Conceptualizing Stigma," Link \& Phelan state that stigmatization is a process, "entirely dependent on the social, economic, and political power necessary to impose discriminatory experiences on the labeled individual or group" (Link \& Phelan 372). Labeling Hetty, in this sense, becomes a way in which Hayslope community controls its second sex non-aristocratic citizens. Discussing the "power of stigmatizing," Falk likewise asserts that the social labels are so powerful that sometimes they stay with the persons till the end of their lives. Performing its power through stigmatization and punishment, society later "restores" the outcast's piety. "Those who are considered impure" according to Falk, "are isolated from ordinary society until their purity is restored by a variety of rituals," for instance, through deportation and exile (311).

Eliot demonstrates Hetty's sudden isolation from society, caused by Hayslope's abandonment, by refraining from narrating these sections. In other words, the author herself, as a member of the Victorian society, leaves Hetty alone. The reader loses track of Hetty after Chapter 37, when the inner voice of the character is no more audible. Hetty, whose "native power of concealment" (338) has already thought her how to conceal herself from society - in the chamber, among the "treesstudded hedgerows," in the hidden "shelter" beside the sheep, and finally in the prison cell, as if she has "no other existence than a hidden one" (388) - succumbs to complete silence as the narrator waits for the witnesses to narrate the rest of the story. Why is the narrator unwilling to follow the criminal woman? Is she afraid? Depriving Hetty of voice and presence, Eliot is making room for society. In its full capacity, society then takes hold of her narrative. Is Eliot the second social outcast, deprived of her storytelling rights?

After hearing about Hetty's imprisonment, Old Mr. Poyser says, "I will not go nigh her, nor ever see her again... she made our bread bitter to us for all of our lives to come" (432). Only Dinah, her feminine equal, recognizes Hetty. It is through religion that Dinah fully embraces Hetty. According to the Methodist beliefs, God, the higher being, cannot act unless the lower beings sin. Jesus, for Dinah, is equal to forgiveness, which cannot operate without sin. Dinah sees herself a person through whom God directly speaks but who needs Hetty, the sinner, to reestablish her position. Dinah who cannot step beyond the limitations of piety likewise fails to restore Hetty at the gallop. This scene may reiterate Eliot's plead against judgment, made earlier in the novel, when she says:

There are so many of us, and our lots are so different, what wonder that Nature's mood is often in harsh contrast with the great crisis of our lives? We are children of a large family, and must learn, as such children do, not to expect that our hurts will be made much of-to be content with little nurture and caressing, and help each other the more (306).

Dinah cannot help Hetty "all the more" until she breaks free from the compulsion to judge. Imagining Hetty as ignorant Dinah constructs basis of her own piety. Eliot, however, has challenged this black and white moral standard. Hetty, we read, has "her peculiar form of worship" (155). Her 
"passionate love of life" (404) is her special form of worship. Blaming Dinah her passive trust in God, Mrs. Poyser declares that "if everybody'ud be running after everybody else to preach to 'em, istead o' bringing up their families, and laying by against a bad harvest. It stands to sense as that can't be the right religion" (80). Sitting with Hetty in the darkness of prisoner's cell, Dinah feels the approach of Hetty's darkness, we read "it got darker and darker... she [Dinah] felt divine presence more and more" (468). In the darkness of Hetty's misery Dinah observes divinity. Dinah “is not the less sinking into the dark gulf" (468). As Dinah's voice eloquently articulates mankind's suffering through the "cross," the reader knows Hetty is the cross-bearer. When later in her song Dinah addresses Jesus to bestow her an easy yoke: "Jesus! the weary wonderer's rest /Give me thy easy yoke to bear" (511). We know whom the "wonderer" and the bearer of the yoke is.

From this, we might attempt to read Eliot's novel as a simple reminder to refrain from judging others. Yet, if this is the code for understanding, Eliot herself breaks it often. For instance, when she gives us two descriptions of Arthur Donnithorne: the way the commoners see him and the way Eliot wants us to see him. Though he's in the militia, not the army, the people of Hayslope saw him as "more intensely [as] a captain than all the young gentlemen of the same rank in his Majesty's regulars--he outshone them as the planet Jupiter outshines the Milky Way" (62). He's a hero to the commoners, but to the author, Arthur is the "well-washed, high-bred, white handed" young Englishman she insists we all know (62). From his description, we must view Arthur as a type of person rather than a person, similar to the way he reduces Hetty to a "pretty butter-maker" (105), despite that she is Hayslope's most desired catch, as shown in the way Adam and the others pine for her throughout most of the novel. In this way, Eliot will not allow her readers to indulge in such simple interpretation, 'do not judge,' and requires us to make several judgments of character thought the narrative. In the end, we learn that Arthur is more than just the simple Englishman Eliot asked us to see at first. The dead infant likewise becomes a "gift" (Dillon 712) through which the narrator challenges the fixed moral standards based on which Hayslope judged and stigmatized Hetty. This is where Eliot, as Douglas Kneale precisely puts it, "points beyond a strictly juridical binarism of guilty/not guilty toward the more complicated ethical question of "how far a man is to be held responsible for the unforeseen consequences of his own deed"' (Kneale 468).

\section{References}

Beer, Gillian. 1983. "Darwin's Plots: Evolutionary Narrative in Darwin, George Eliot, and Nineteenth Century Fiction.” London, Boston, Melbourne, and Henley: Routledge \& Kégan Paul, Web.

Berger, Courtney. 2000. "When Bad Things Happen to Bad People: Liability and Individual

Consciousness in Adam Bede and Silas Marner". NOVEL: A Forum on Fiction 33.3: 307-327. Web.

Dillon, Steven. 1992. "George Eliot and the Feminine Gift". Studies in English Literature, 1500 - 1900 32.4: 707-721. Web.

Eliot, George. 1980. Adam Bede. New York: Penguin Classics, Print. 
Falk, Gerhard. 2001. Stigma: How We Treat Outsiders. Amherst, N.Y: Prometheus Books, Print. Foucault, Michel. 1980. "Prison Talk." C. Gordon (Ed.), Power/knowledge: Selected Interviews and Other Writings, 1972-1977. New York: Pantheon. pp. 37-54.Web.

Goffman, Erving. 1986. Stigma Notes on the Management of Spoiled Identity. New York: Touchstone, Print.

Heatherton, Todd F., Robert E. Kleck, Michelle R. Hebl, Jay G. Hull. 2003. The Social Psychology of Stigma. New York: The Guilford P, Print.

Kneale, Douglas. "Hetty's Hanky.” 2015. ESC: English Studies in Canada 1.2: 123-150. Project MUSE. Web. 11 Dec. 2015. Web.

Marck, Nancy Anne. 2003 "Narrative Transference and Female Narcissism: The Social Message of Adam Bede". Studies in the Novel 35.4: 447-470. Web.

Marr, Ryan. 2014. "Dinah Morris as Second Eve: The Fall and Redemption in Adam Bede." Logos: A Journal of Catholic Thought and Culture 17.3: 80-102. Project MUSE. Web.

Phelan, J. C. and B. G. Link. 2001. "Conceptualizing Stigma.” Annual Review of Sociology, 27: 363 -85 . Web.

Scheyett, Anna. 2007. The Mark of Madness: Stigma, Serious Mental Illnesses, and Social Work. Retrieved: February 2007. Print. 